\title{
PERANAN WARGA TIONGHOASEBAGAI ANGGOTA LEGISLATIFDI KOTA BATAM TAHUN 1999-2009
}

\author{
Fitri Yanti, Nunung Krisnawati \\ Fakultas Keguruan dan Ilmu Pendidikan, Universitas Riau Kepulauan \\ fty_ipit@yahoo.co.id
}

\begin{abstract}
The background of this thesis is an increasing number of legislators Batam from Chinese citizens, at the 1999 elections, there were two people who passed to the DPRD Kota Batam, in the elections of 2004 increased to four Chinese citizens who become legislators Batam. It is not independent of their role during the sitting in the legislature as a representative of the people. This study aims to clarify the role of Chinese citizens who sat as a legislative member in Batam 1999-2009

This research is a qualitative research, the historical method with the approach of political science. Steps historical research include: first heuristic, there are two sources of data are primary data and secondary data, primary data in this study is a member of the legislative representatives of the Chinese community, Chinese people, community leaders and members of the Commission, the secondary data taken from any books, newspapers and other documents, the authors do critique source consisting of external criticism and internal criticism, the three researchers to interpret, fourth historiography.

The results in this study explained that the role of the Chinese community as a member of the legislature in Batam years 1999-2009, the first legislative function is set statutorily in the form of local regulations (Perda), the second control function or supervise the activities of local government in implementing legislation has been agreed, of these control functions legislators have the right to ask questions, interpellation, questionnaires and motions, the three other functions related to the budget or APBD that has been agreed with the local governments when the plenary session.
\end{abstract}

Keywords: legislative member, chinese society

\begin{abstract}
Abstrak
Latar belakang penelitian ini adalah terjadinya peningkatan jumlah anggota DPRD Kota Batam dari warga Tionghoa, dimana pada pemilu tahun 1999 terdapat dua orang yang lolos menjadi anggota DPRD Kota Batam dan pada pemilu tahun 2004 mengalami peningkatan menjadi empat orang. Hal ini tentunya tidak terlepas dari peran mereka selama duduk di legislatif sebagai wakil rakyat. Penelitian ini bertujuan untuk menjelaskan peran warga Tionghoa yang duduk menjadi anggota legislatif di Kota Batam tahun 1999-2009.

Jenis penelitian ini adalah penelitian kualitatif historis dengan pendekatan ilmu politik.Adapunlangkah-langkah penelitian historis meliputi: pertama heuristik, di dalamnya terdapat dua sumber data yaitu data primer dan data
\end{abstract}


sekunder, data primer dalam penelitian ini adalah anggota legislatif dari perwakilan masyarakat Tionghoa, masyarakat keturunan Tionghoa, tokoh masyarakat dan anggota KPU, data sekunder diambil dari buku-buku, koran dan dokumen lainnya.Kedua, kritik sumber yang terdiri dari kritik ekstern dan kritik intern.Ketiga, interpretasi dan keempat, historiografi.

Hasil dalam penelitian ini menjelaskan bahwa peranan warga Tionghoa sebagai anggota legislatif di Kota Batam tahun 1999-2009, pertama fungsi legislasi yaitu mengatur undang-undang dalam bentuk peraturan daerah (Perda), kedua fungsi kontrol atau mengawasi kegiatan pemerintah daerah dalam menjalankan Perda yang telah disepakati, dari fungsi kontrol ini anggota DPRD memiliki hak untuk bertanya, interpelasi, angket dan mosi, ketiga fungsi lainnya yang berkaitan dengan anggaran atau APBD yang telah disepakati bersama pemerintah daerah saat sidang paripurna. Bermainnya peran-peran tersebut dengan baik, semakin menambah nilai kepercayaan warga Tionghoa memilih dari kalangan mereka untuk pemilu selanjutnya.

Kata Kunci: anggota legislatif, masyarakat tionghoa, kota batam

\section{A. Latar Belakang Masalah}

Pada masa pemerintahan Hindia Belanda sampai Presiden Soekarno, warga Tionghoa diberi kebebasan dalam mengekspresikan seni budaya dan tradisi leluhur mereka. Sampai meletusnya Gerakan G.30Spada tahun1965 yang mengakibatkan runtuhnya pemerintahan Soekarno (Orde Lama) dan digantikan oleh pemerintahan Soeharto (Orde Baru), posisi warga Tionghoa di Indonesia mulai terganggu. Warga Tionghoa dicurigai masih memiliki ikatan yang kuat dengan tanah leluhurnya sehingga rasa nasionalisme mereka diragukan. Akibatnya, keluarlah kebijakan yang sangat diskriminatif terhadap warga keturunan Tionghoa baik dalam bidang politik maupun bidang sosial budaya, yang tertuang dalam Inpres No.14 tahun 1967 dan Surat Edaran No. 06/Preskab/6/67 yang memuat tentang Perubahan Nama. Warga keturunan Tionghoa yang berada di Indonesia harus mengubah nama Cina-nya menjadi nama Indonesia. Kemudian tidak hanya itu, semua kegiatan warga Tionghoa diawasi oleh Badan Koordinasi Intelijen (Bakin). Pengekangan aktivis sosial keagamaan warga Tionghoa oleh pemerintah Orde Baru diberlakukan diseluruh wilayah Indonesia (Sutrisno, 2006: 117).

Kebijakan tersebut berakhir setelah Soeharto lengser dari kepemimpinannya pada tanggal 21 Mei 1998, dengan adanya demo besar-besaran yang dilakukan oleh mahasiswa di Indonesia. Runtuhnya kepemimpinan Soeharto yang digantikan B.J Habibie telah memberikan ruang bagi warga Tionghoa untuk melakukan aktivitas di bidang religi, sosial, budaya. Hal ini dibuktikan dengan 
terbentuknya Paguyuban Sosial Marga Tionghoa Indonesia (PSMTI) di Jakarta yang diketuai oleh Brigjen TNI (Purn) Tedy Jusuf (Suryadinata, 2002: 94-95).

Kemudian pemerintahan Abdurrahman Wahid telah mencabut Inpres No. 14 tahun 1967 dengan mengeluarkan Keputusan Presiden No. 6 tahun 2000.Keluarnya peraturan perundangan tersebut membuat kegiatan seni dan budaya warga Tionghoa mulai diadakan kembali.Keputusan Abdurrahman Wahiddisambut baik oleh orang Tionghoa. Kehidupan berdemokrasi semakin baik karena kerukunan antar etnis. Hal ini terlihat diperbolehkannya orang Tionghoa ikut dalam kontestasi politik. Mereka terdiri dari orang-orang berkeinginan untuk mengaspirasikan suara mereka dalam membangun bangsa dan negara Indonesia (Suryadinata, 2002: 97).

Demikian juga di Kepulauan Riau, khususnya di Kota Batam yang memiliki penduduk dari berbagai suku sepertiMelayu, Jawa, Minang, Batak, Tionghoa dan lainnya. Orang Tionghoa memiliki partisipasi aktif dalam pembangunan Kota Batam termasuk bidang politik.Pada pemilu tahun 1999, tidak sedikit warga Tionghoa di Batam yang turut serta memperebutkan kursi Legislatif di DPRD Batam. Hal ini ditandai dengan warga Tionghoa menjadi Calon Legislatif (Caleg) DPRD yang tersebar di 33 (tigapuluh tiga) Parpol sebagai peserta pemilu tahun 1999-2004 (Sutrisno, 2006: 109).

Perkembangan warga Tionghoa yang turut serta dalam pemilu dan berhasil duduk di kursi DPRD Kota Batam adalah :

1. Pemilu periode 1999-2004 yang lolos duduk menjadi anggota DPRD Kota Batam ada 2 orang yaitu Saptono Mustakim mewakili Partai Bhinneka Indonesia (PBI) dan Asmin Patros mewakili Partai Golongan Karya (Golkar).

2. Pemilu periode 2004-2009 yang lolos duduk menjadi anggota DPRD Kota Batam ada 4 orang yaitu Yohannes mewakili Partai Perjuangan Indonesia Baru (PPIB), Bastoni Solichi dan Danir Tan mewakili Partai Demokrat sedangkan Asmin Patros mewakili Partai Golkar

Dengan terjadinyapeningkatan jumlah anggota legislatif dari warga Tionghoa pada Pemilu tahun 1999 dan Pemilu tahun 2004 di Kota Batam, tentunya tidak terlepas dari peranan-peranan yang mereka mainkan sehingga menarik simpati dari masyarakat khususnya warga Tionghoa. Hal inilah yang menjadi latar belakang penulisan karya ilmiah ini dengan judul peranan warga Tionghoa sebagai anggota legislatif di Kota Batam tahun 1999-2009.

\section{B. Rumusan Masalah}

Berdasarkan latar belakang masalah di atas maka rumusan masalah dalam penelitian ini adalah bagaimana perananpolitik warga Tionghoa yang duduk menjadi anggota legislatif di Kota Batam tahun 1999-2009? 


\section{Tujuan Penelitian}

Adapun tujuan penelitian ini adalah untuk menjelaskan peran warga Tionghoa yang duduk menjadi anggota Legislatif di Kota Batam tahun 19992009 .

\section{Kajian Teori}

\section{Badan Legislatif}

MenurutMiriam Budiardjo (2009: 315), badan legislatif atau legislature mencerminkan salah satu fungsi badan itu yaitu legislate, atau membuat undangundang. Nama lain yang sering dipakai ialah assembly yang mengutamakan unsur "berkumpul" (untuk membicarakan masalah-masalah publik). Nama lain adalah parliament, suatu istilah yang menekankan unsur "bicara" (parler) dan merundingkan. Sebutan lain mengutamakan representasi atau keterwakilan angota-anggotanya dan dinamakan people's representatifbody atau Dewan Perwakilan Rakyat (DPR). Akan tetapi apapun perbedaan dalam namanya dapat dipastikan bahwa badan ini merupakan simbol dari rakyat yang berdaulat.

Dengan berkembangnya gagasan bahwa kedaulatan ada di tangan rakyat makabadan legislatif menjadi badan yang berhak menyelenggarakan kedaulatan itu dengan jalan menentukan kebijakan umum dan menuangkannya dalam undang-undang (UU). Tugas badan eksekutif hanya merupakan penyelenggaraan kebijakan umum(Rohaniah, 2015: 292).

Pendapat lain mengatakan badan legislatif adalah lembaga politik yang diambil alih dari masyarakat lain maka bagi anggota yang mengoperasikan lembaga tersebut diperlukan kadar pemahaman yang cukup atas prinsip-prinsip dan tata kerja institusi. Akan tetapi apa pun perbedaan dalam namanya dapat dipastikan bahwa badan ini merupakan simbol dari rakyat yang berdaulat (Sanit, 1985: 207).

Lembaga legislatif atau parlemen dalam pelaksanaan semua peran dan fungsinya melakukan hubungan dengan eksekutif dalam wujud kerja sama atau pertentangan (perbedaan) yang terkombinasi dalam kadar yang berbeda. Jika hubungan tersebut diurutkan berdasarkan keseluruhan tahapan proses lembaga perwakilan maka konsentrasi hubungan itu dapat disusun atas hubungan keanggotaan, usulan rencana kebijakan, pembuat kebijakan, perbaikan kebijakan dan pelaksanaannya. Menurut Rohaniah (2015: 296) terdapat tiga fungsi legislatif yaitu :

\section{a. Fungsi legislasi}


Tugas utama legislatif terletak di bidang perundang-undangan, sekalipun DPR tidak mempunyai monopoli dibidang itu. Untuk membahas rancangan undang-undang sering dibentuk panitia-panitia yang berwenang untuk memanggil menteri atau pejabat lainnya untuk dimintai keterangan seperlunya. Pada umumnya dalam bidang keuangan, pengaruh badan legislatif lebih besar dari pada bidang legislasi umum. Rancangan anggaran belanja diajukan ke badan legislatif oleh badan eksekutif, tetapi badan legislatif mempunyai hak untuk mengadakan amandemen, dalam hal ini menentukan seberapa anggaran pemerintah yang dapat disetujui, jadi badan legislatiflah yang akhirnya menentukan berapa dan dengan cara bagaimana uang rakyat dipergunakan.

\section{b. Fungsi kontrol}

Badan legislatif berkewajiban untuk mengawasi aktifitas badan eksekutif, agar sesuai dengan kebijakan yang telah ditetapkannya. Pengawasan dilakukan melalui sidang panitia-panitia legislatif dan melalui hak-hak kontrol yang khusus, seperti :

1. Pertanyaan parlementer

Anggota badan legislatif berhak untuk mangajukan pertanyaan kepada pemerintah mengenai suatu masalah. Peraturan di Indonesia untuk semua badan legislatif, kecuali badan legislatif Gotong Royong di zaman Demokrasi Terpimpin, mempunyai hak bertanya. Pertanyaan ini biasanya diajukan secara tertulis dan dijawab pula secara tertulis oleh departemen yang bersangkutan. Badan legislatif dengan mengajukan pertanyaan kepada parlementer dapat menarik perhatian umum mengenai kebijakan pemerintah.

2. Interpelasi

Hak interpelasi yaitu hak untuk meminta keterangan kepada pemerintah mengenai kebijakan di suatu bidang. Badan eksekutif wajib memberi penjelasan dalam sidang pleno yang dibahas oleh anggota DPR dan diakhiri dengan pemungutan suara mengenai apakah keterangan pemerintah memuaskan atau tidak. Jika hasil pemungutan suara tidak memuaskan, hal ini menandakan bahwa kebijakan pemerintah diragukan. Dalam hal ini, telah terjadi perselisihan antara badan legislatif dengan badan eksekutif, interpelasi dapat dijadikan batu loncatan untuk diajukan mosi tidak percaya.

Seluruh badan legislatif di Indonesiakecuali Dewan Perwakilan Rakyat (DPR) Gotong Royong pada masa Demokrasi Terpimpin, mempunyai hak interpelasi. Pada masa orde baru, hak interpelasi tidak pernah digunakan. Hak ini kembali digunakan pada Era Reformasi ketika DPR tahun 2004-2009 mengusung interpelasi masalah impor beras dan lumpur Lapindo. Usaha anggota dewan ini akhirnya gagal karena tidak memenuhi jumlah yang sudah ditentukan. 


\section{Angket}

Hak angket adalah hak anggota badan legislatif untuk mengadakan penyelidikan sendiri. Terkait dengan hal ini maka dapat dibentuk panitia angket yang melaporkan hasil penyelidikan kepada anggota badan legislatif lainnya untuk selanjutnya merumuskan pendapatnya mengenai penyelidikan dengan harapan supaya diperhatikan oleh pemerintah.

Peraturan di Indonesia,untuk semua badan legislatif kecuali Dewan Perwakilan Rakyat (DPR) Gotong Royong pada zaman Demokrasi Terpimpin mempunyai hak angket. Namun, hak ini tidak pernah digunakan kecuali oleh anggota DPR pada masa Reformasi tahun 2004-2009 untuk masalah impor beras.

4. Mosi

Hak mosi merupakan hak kontrol yang paling ampuh. Jika badan legislatif menerima suatu mosi tidak percaya maka dalam sistem Parlementerkeanggotaan dalam kabinet harus mengundurkan diri yang mengakibatkan terjadinya krisis kabinet. Sistem Parlementer di Indonesia untuk badan legislatif mempunyai hak mosi tetapi mulai zaman Demokrasi Terpimpin hak ini ditiadakan. Pada masa Reformasi, anggota DPR tahun 19992004 menggunakan hak mosi ketika melakukan pemakzulan Presiden Abdurahman Wahid sebagai Presiden tahun 2001. Hal ini memang tidak lazim karena umumnya hak ini digunakan dalam sistem Parlementer dan bukan sistem Presidensial.

\section{c. Fungsi lainnya}

Selain fungsi legislasi dan kontrol, badan legislatif mempunyai beberapa fungsi lain. Dengan meningkatkan peranan badan eksekutif dan berkurangnya peranan badan legislatif di bidang perundang-undangan karena lebih ditonjolkan peran edukatifnya. Badan legislatif dianggap sebagai forum kerjasama antar berbagai golongan serta partai dengan pemerintah, dimana beraneka ragam pendapat dibicarakan di muka umum.

Bagi anggota badan legislatif terbuka kesempatan untuk bertindak sebagai pembawa suara rakyat dan mengajukan beraneka ragam pandangan yang berkembang secara dinamis dalam masyarakat. Dengan demikian jarak (gap) antara yang memerintah dengan yang diperintah dapat diperkecil. Pada pihak lain, pembahasan kebijakan pemerintahdi muka umum merupakan kesempatan bagi pemerintah seperti untuk menjelaskan tindakan-tindakan secara rencana.Dapat di jelaskan bahwa fungsi lain yang tidak kalah pentingnya yaitu sebagai sarana rektrumen politik yang menjadikan training ground bagi generas muda di bidang politik (Budiardjo, 2009: 323).

Dengan demikian fungsi legislatif adalah (1) fungsi legislasi yaitu bertugas dalam bidang perundang-undangan, (2) fungsi kontrol yang berkewajiban 
untuk mengawasi aktifitas badan eksekutif sesuai dengan kebijakan yang telah ditetapkan, melalui hak-hak kontrol yang khusus seperti hak bertanya, interpretasi, angket dan mosi, (3) fungsi lainnya yaitu sebagai sarana rektrumen politik.

Melihat uraian di atas, penelitian ini akan mengarah kepada peranan dari warga Tionghoa yang menjadi anggota DPRD kota Batam tahun 1999 - 2009 sebagai penyambung aspirasi rakyat Batam. Peranan tersebut diteliti dari fungsi legislasi, fungsi kontrol dan fungsi lainnya sebagai wakil rakyat kota Batam.

\section{Politik dan Partai Politik}

Hafsah (2011: 13) mengatakan istilah politik muncul untuk pertama kalinya dalam litelatur Yunani klasik lewat karya Plato yang terkenal yaitu politea (kiat memimpin kota/polis).Politik menurut teori klasik Aristoteles adalah usaha yang ditempuh warga negara untuk mewujudkan kebaikan bersama. Politik diasumsikan setidaknya ke dalam dua kecenderungan, pertama pandangan yang mengaitkan politik dengan negara dan kedua pandangan yang mengaitkan dengan kekuasaan, otoritas, atau dengan konflik.

Menurut George Washington (dalam Imam Hidajat, 2012: 3) politik merupakan sistem kekuasaan yang didalamnya tidak boleh terdapat adanya kediktatoran/kekuasaan yang mutlak (absolut), melainkan didalamnya harus terdapat perpindahan kekuasaan dari satu tangan yang lain lewat cara damai. Laswell mendefinisikan politik sebagai who gets what, when and how (siapa mendapatkan apa, kapan, dan bagaimana). Eston menyebutnya sebagai "the authoritative allocation of value" (kekuasaan untuk mengalokasikan sumbersumber yang terbatas) (Hafsan, 2011: 14).

Berpolitik secara santun merefleksikan kematangan berdemokrasi. Namun kematangan itu bukanlah sesuatu yang instan tetapi melalui berbagai proses. Pengalaman berproses inilah yang mampu mendewasakan sikap politisi menuju kearifan langkah. Alangkah beruntungnya negeri ini jika berpolitik selalu dinaungi kedisiplinan moral berbasis religi (Hafsah, 2011: 12).

Berdasarkan penjelasan diatas maka dapat disimpulkan bahwa politik mengandung tiga pengertian dasar sebagai berikut pertama, segala urusan dan tindakan (pengaturan, kebijakan, kewenangan, kekuasaan dsb) mengenai pemerintahan negara atau hubungan antara manusia yang hidup bersama.Kedua, politik adalah pengetahuan mengenai ketatanegaraan atau kenegaraan (seperti: sistem politik, sistem pemerintah, atau dasar pemerintah). Ketiga, aktivitas yang berkaitan dengan bermasyarakat, berbangsa, bernegara dan berhubungan dengan pengguna kekuasaan negara (Rohaniah, 2015: 3).

Anggota legislatif berasal dari partai politik. Partai Politik (Parpol) merupakan sarana bagi warga negara untuk turut serta/berpartisipasi dalam proses 
pengolahan negara. Dalam suatu lembaga politik, partai bukan sesuatu yang dengan sendirinya ada. Kelahirannya mempunyai sejarah cukup panjang,meskipun juga belum cukup tua, dapat dikatakan parpol merupakan organisasi negara (Rohaniah, 2015: 249).

Pendapat Carl J. Friedrich (dalam Miriam Budiardjo,2009: 404) mengatakanpartai politik adalah sekelompok manusia yang terorganisir secara stabil dengan tujuan merebut atau mempertahankan penguasaan terhadap pemerintahan bagi pimpinan partainya dan berdasarkan penguasaan ini, memberikan kepada anggota partainya kemanfaatan yang bersifat idiil serta materiil.

Septe Nurwijayanti dan Nanik Prasetyoningsih (2009: 16) tujuan umum partai politik dan tujuan khusus partai politik diatur dalam Pasal 10 UU Nomor 2 tahun 2008. Tujuan umumnya adalah:

1) Mewujudkan cita-cita nasional bangsa Indonesia sebagaimana dimaksudkan dalam Pembukaan Undang-Undang Dasar Negara Republik Indonesia Tahun 1945.

2) Menjaga dan memelihara keutuhan Negara Kesatuan Republik Indonesia.

3) Megembangkan kehidupan demokrasi berdasarkan Pancasila dengan menjunjung tinggi kedaulatan rakyat dalam Negara Kesatuan Republik Indonesia, dan

4) Mewujudkan kesejahteraan bagi seluruh rakyat Indonesia.

Adapaun tujuan khusus partai politik adalah :

1) Meningkatkan partisipasi politik anggota dan masyarakat dalam rangka penyelenggaraan kegiatan politik dan pemerintahan.

2) Memperjuangkan cita-cita partai politik dalam kehidupan bermasyarakat, berbangsa dan bernegara.

3) Membangun etika dan budaya politik dalam kehidupan bermasyarakat, berbangsa dan bernegara.

Secara umum dapat dikatakan bahwa partai politik adalah suatu kelompok terorganisir yang anggota-anggotanya mempunyai orientasi, nilai-nilai, dan citacita yang sama. Tujuan kelompok ini ialah memperoleh kekuasaan politik dan merebut kedudukan politik (biasaya) dengan cara konstitusional untuk melaksanakan programnya (Budiardjo,2009: 403).

\section{Kebijakan politik}

Menurut Miriam Budiardjo (2009: 20) kebijakan (policy) adalah suatu kumpulan keputusan yang diambil oleh seorang pelaku atau kelompok politik dalam usaha memilih tujuan dan cara untuk mencapai tujuan itu. Pada prinsipnya pihak yang membuat kebijakan-kebijakan itu mempunyai kekuasaan untuk melaksanakannya. 
Pemerintah dalam melaksanakan tugas akan bertindak atas nama negara. Hal-hal tersebut berupa keputusan politik, atau kebijakan/policy/output/kebijakan pemerintah. Pemerintah dalam hal ini mengatur masyarakat melalui kebijakan, dan kebijakan ini harus dapat dipatuhi. Oleh karena itu pemerintah memiliki struktur kekuasaan yang memonopolitik penggunaan paksaan fisik yang sah terhadap rakyat yang tinggal dalam wilayah yang jelas batas-batasnya (Rohaniah, 2015: 86).

Menurut Joyce Mitchelle (dalam Miriam Budiardjo, 2009: 20) mengatakan Political and Public Policy artinya politik adalah pengambilan keputusan kolektif atau pembuatan kebijakan umum untuk masyarakat seluruhnya. Dengan adanya kebijakan masyarakat mempunyai beberapa tujuan bersama, cita-cita bersama yang dicapai melalui usaha bersama, untuk itu perlu ditentukan rencana-rencana yang mengikat dan dituangkandi dalam kebijakan (policies) oleh pihak yang berwenang yaitu pemerintah.

Pemahaman akan pentingnya kebijakan telah dijadikan tata kelola oleh setiap negara modern sehingga negara modern menganggap bahwa sistem politik yang ideal adalah demokrasi, sehingga demokrasi artinya pelibatan rakyat dalam proses politik yang tidak berhenti setelah pemilihan umum (Pemilu) usai dan kemudian para wakil rakyat bebas mendiktekan kemauannya "atas nama kepentingan rakyat". Masyarakat dapat melihat kebijakan sebagai suatu legitimasi, tujuan-tujuan subtantif, instrumen dan hasil kebijakan harus sejajar dengan sentimen umum yang hadir dimasyarakat, jika bukan dari nilai-nilai yang umum dimasyarakat (Rohaniah, 2015: 84)

\section{Tionghoa Indonesia}

Leluhur warga Tionghoa ke Indonesia datang lebih awal dibandingkan dengan bangsa Belanda, dengan tujuan awal untuk berniaga.Peran mereka beberapa kali muncul dalam sejarah Indonesia, bahkan sebelum Republik Indonesia dideklarasikan dan terbentuk. Catatan-catatan dari Tiongkok menyatakan bahwa kerajaan-kerajaan kuno di Indonesia telah berhubungan erat dengan dinasti-dinasti yang berkuasa di Tiongkok. Faktor inilah yang kemudian menyuburkan perdagangan dan lalu lintas barang maupun manusia dari Tiongkok menuju Indonesia (http://wattpad.com diunduh pada tanggal 9 Maret 2016).

Suku Tionghoa yang tersebar di Indonesia antara lain (1) Hokkian, orang Hokkian di Indonesia tersebar di daerah Sumatera Utara, Riau (Pekan Baru), Sumatera Barat (Padang), Sumatera Selatan (Palembang), Bengkulu, Jawa, Bali, Kalimantan, Sulawesi dan Ambon. (2) Hakka, orang Hakka tersebar di daerah Jakarta, Aceh, Sumatera Utara, Batam, Sumatera Selatan (Palembang), BangkaBelitung, Lampung, Jawa, Kalimantan, Makasar, Manado, Ambon dan Jayapura. (3) Kanton, orang Kanton di Indonesia tersebar di daerah Jakarta, Medan, 
Makassar dan Manado. (4) Tiochiu, orang Tiochiu di Indonesia tersebar di daerah Sumatera Utara, Riau, Kepulauan Riau, Jambi, Sumatera Selatan dan Kalimantan Barat. (5) Hainan, orang Hainan di Indonesia tersebar di daerah Pekan Baru, Batam dan Manado. Suku Tionghoa yang berada di wilayah Batam adalah dari suku Hakka dan Hainan (http://wwwdiunduh pada tanggal 9 Mei 2016).

Masyarakat Tionghoa di Indonesia bukan merupakan minoritas homogen. Melihat dari sudut kebudayaan, orang Tionghoa terbagi atas peranakan dan totok. Peranakan adalah orang Tionghoa yang sudah lama tinggal di Indonesia dan pada umumnya sudah berbaur. Mereka berbahasa Indonesia sebagai bahasa sehari-hari dan bertingkah laku seperti pribumi. Totok adalah pendatang baru, umumnya baru satu sampai dua generasi dan masih berbahasa Tionghoa. Namun dengan berhentinya imigrasi dari daratan Tiongkok, jumlah totok sudah menurun dan keturunan totok pun telah mengalami percampuran. Oleh karena itu, generasi muda Tionghoa di Indonesia sebetulnya sudah menjadi peranakan apalagi yang di pulau Jawa (Suryadinata, 2002: 17).

Dalam sastra Indonesia-Tiongkok dapat juga kita lihat pencerminan kebudayaan Tiongkok. Tidak banyak, karena orang Tionghoa-Peranakan, yang sudah tidak dapat membaca huruf Tionghoa dan tidak dapat berbicara dalam bahasa Tionghoa lagi, dengan peredaran waktu semakin lama semakin jauh dari kebudayaan Tiongkok (Lan, 2013: 310).

Warga Tionghoa di Indonesia memiliki peranan yang cukup penting bukan saja dibidang ekonomi, namun bidang lainnya seperti sosial, budaya dan politik. Warga Tionghoa dalam bidang ekonomiterkenal dengan pekerja keras, rajin dan giat bekerja. Bidang sosial, budaya dan politik, warga Tionghoa di Indonesia sempat mengalami diskriminasi saat pemerintahan Soeharto. Runtuhnya pemerintahan soeharto maka mulai muncul kembali tradisi Tionghoa di tegahtengah masyarakat indonesia (Suryadinata, 2002: 7).

Masyarakat Tionghoa Batam juga kembali menghidupkan kepercayaan tradisi mereka, seperti pergantian Tahun Imlek atau Sin Tjie, perayaan Cap Go Meh, Pertunjukan Seni Barongsai kembali digelar (Sutrisno, 2006: 118). Masingmasing suku Tionghoa di Batam memiliki dialek yang berbeda-beda, tetapi mereka memiliki satu bahasa yang dapat dipahami secara umum yaitu Bahasa Mandarin. Selain bahasa Mandarin warga Tionghoa yang berada di Batam juga menggunakan dialek bahasa Tiochiu, bahasa Hokkian, bahasa Kontanis dan bahasa Hakka. Di Batam mayoritas warga Tionghoa menggunakan bahasa Mandarin sebagai bahasa komunikasi sehari-hari dan sebagai keanekaragaman khasanah budaya di Kota Batam (Sutrisno, 2006: 130-133). 


\section{Metode Penelitian}

\section{Jenis Penelitian}

Jenis penelitian ini adalah penelitian kualitatif, metodehistoris dengan pendekatan ilmu politik..Louis Gottschalk (1983: 18-19) menyatakan, metode historis sebagai proses menguji dan menganalisis secara kritis rekaman, dokumendokumen, dan peninggalan masa lampau yang autentik dan peninggalan masa lampau yang autentik dan dapat dipercaya serta membuat interpretasi dan sintesis atas fakta-fakta tersebut menjadi kisah sejarah yang dapat dipercaya.Sedangka pendekatan ilmu politik digunakan untuk mengkaji peranan dari warga Tionghoa yang duduk menjadi anggota DPRD Kota Batam tahun 1999-2009.

\section{Tempat Penelitian}

Tempat penelitian dilakukan di wilayah Kota Batam. Pengumpulan data primer dan sekunder dilakukan di kantor DPRD Kota Batam, kemudian pengumpulan sumber sekunder dilaksanakan di berbagai perpustakaan di Kota Batam, seperti perpustakaan pemerintahan Kota Batam, perpustakaan Otorita Batam, perpustakaan Universitas Riau Kepulauan Batam dan perpustakaan lainnya.

\section{Metode Penelitian}

Dalam metode penelitian ini Historis langkah-langkah yang dilakukan meliputi :

\section{a. Heuristik}

Kuntowijoya, (2008: 91) metode heuristik adalah langkah-langkah untuk mencari dan menentukan sumber-sumber yang relevan dengan penelitian.Dalam hal ini langkah kegiatan pengumpulan data yang berupa arsip-arsip tentang datawarga Tionghoa yang duduk di kursi DPRD Kota Batam tahun 1999-2009, dibagi 2 yaitu data primer dan data sekunder. Data primer diambil dari dokumen /arsip kinerja DPRD Kota Batam dan wawancara terhadap beberapa tokoh Tionghoa yang menjadi anggota DPRD Kota Batam dari tahun 1999-2009. Peneliti akan mengumpulkan informasi dari informan seperti masyarakat keturunan Tionghoa dan masyrakat pribumi yang berada di Batam, terkait tentang tanggapan mereka terhadap kinerja warga Tionghoa yang duduk di kursi DPRD Kota Batam tahun 1999-2009. Hasil wawancara akan tersimpan dalam bentuk 
voice record atau rekaman suara sebagai sumber lisan. Selain sumber lisan penulis juga menggunakan sumber tulisan berupa data-data terkait tentang keputusan keanggotaan DPRD Kota Batam. Sedangkan data sekunder dapat berupa data-data referensi atau pustaka dalam penelitian ini seperti berupa buku, artikel, jurnal sebagai sumber pendukung data sekunder, peneliti akan mengambil data dari kantor DPRD Kota Batam tentang warga Tionghoa, terkait data tentang pemilu tahun 1999 dan 2004. selain itu data-data berupa foto menjadi sumber penting, melalui foto dapat dijelaskan kondisi keanggotaan DPRD Kota Batam tahun 1999-2009.

\section{b. Kritik sumber}

Kritik sumber adalah penilaian atau tahap pengujian terhadap sumbersumber sejarah yang telah dikumpulkan dan dilihat dari sudut pandang nilai kebenarannya. Pada tahap ini untuk melihat sumber tersebut asli atau turunan, kritik sumber terbagi menjadi 2 yaitu ritik ekstern, merupakan penilaian untuk meneliti keaslian sumber yang lebih menekankan pada isi sebuah dokumen. Kritik ekstern mengarah pada pengujian terhadap aspek luar dari sumber (warna kertas), seperti dokumen atau arsip meliputi kertas dengan jenis, ukuran, bahan, kualitas. Dokumen ditulis dengan tangan atau diketik/ketik komputer.Kritik internmerupakan penilaian untuk meneliti kredibilitas sumber dalam penelitian. Tujuan dari kritik intern adalah menyeleksi data menjadi fakta, dengan membandingkan beberapa penafsiran dari beberapa sumber yang diperoleh.Pada tahap ini peneliti akan melakukan wawancara dan mengumpulkan data hasil wawancara terhadap seluruh informan terkait tentangperanan warga Tionghoa yang menjadi anggota legislatif di Kota Batam tahun 1999-2009. Selanjutnya peneliti juga melakukan kritik hasil wawancara tersebut terkait kinerja warga Tionghoa di Kota Batam yang menjadi anggota DPRD tahun 1999-2009. Hal ini dilakukan sebagai pengecekan proses-proses serta untuk mendetekasi adanya kekeliruan yang mungkin saja terjadi.

\section{c. Interpretasi}

Sartono Kartodirjo (1976: 5) berpendapat dalam tahapan interpretasi merupakan proses penyusunan deskripsi, narasi dan analisa sejarah dalam bentuk konsep narasi sejarah masih dalam bentuk abstrak yang diwujudkan dalam ide-ide penulis mengenai fenomena kesejarahan. Penyusunan interpretasi digunakan untuk mempertajam dan sebagai penuntun analisa dalam narasi sejarah, yang dibuat dengan menggunakan bantuan dari ilmu lainnya dalam bentuk konsep atau teori yang diperlukan dalam menganalisis data.

Interpretasi data mengenai sejarah warga Tionghoa yang menjadi anggota legislatif Kota Batam tahun 1999-2009, disesuaikan dengan data-data yang 
diperoleh dari sumber-sumber yang diteliti. Proses interpretasi sangat membutuhkan berbagai tinjauan dan analisis guna meningkatkan kepekaan peneliti dalam menilai fenomena yang ada.

\section{d. Historiografi}

Historiografi yaitu proses penyusunan fakta-fakta sejarah dan sumbersumber yang telah diseleksi dalam sebuah bentuk penulisan sejarah. Setelah dilakukan dari berbagai tahapan, penulis menyadari bahwa hasil penelitian dibaca oleh orang lain sehingga perlu dipertimbangkan gaya dan struktur bahasa penulisan supaya pembaca dapat mengerti pokok-pokok pemikiran penulis tentang peranan anggota legislatif warga Tionghoa di Kota Batam tahun 19992009. Hal ini ditujukan untuk menangkap dan memahami sudut pandang kesejarahan dari segi peneliti.

\section{E. Hasil Penelitian dan Pembahasan}

\section{Temuan Umum}

\section{a. Pembentukan DPRD Kota Batam}

Berdirinya gedung DPRD Kota Batam memiliki sejarah panjang, wilayah Batam yang ditingkatkan statusnya dari pemerintah Kotamadya Administratif menjadi pemerintahan otonom yang tertuang dalam Undang-Undang Nomor 22 tahun 1999 tentang otonomi daerah dan dilanjutkan dengan Undang-Undang Nomor 53 tahun 1999 tentang pemekaran Kabupaten dan Kota di wilayah provinsi Riau sebagai dasar pembentukan Kota Batam. Para aktivis partai politik membentuk Dewan Musyawarah Kota Batam (DMKB) berfungsi sebagai lembaga kontrol terhadap pelaksanaan pemerintah Otorita Batam maupun Pemerintahan Kodya Batam (Sutrisno, 2016: 45).

Awal bulan Mei 1999 keberadaan Dewan Musyawarah Kota Batam semakin banyak mendapat dukungan dari partai politik di Batam, seperti Partai Bhinneka Tunggal Ika (PBI), Partai Buruh Nasional (PBN), Partai Demokrasi Indonesia Perjuangan (PDI Perjuangan), Partai Republik (PR) dan Partai Keadilan dan Persatuan (PKP). Sehingga DMKB diyakini sebagai cikal bakal terbentuknya DPRD Kota Batam untuk pertama kali.

Kesadaran masing-masing partai politik, bahwa mereka tidak dapat berjalan sendiri-sendiri untuk terbentuknya DPRD, mengakibatkan para partai politik kompak dan menyatukan persepsi, serta menyatakan visi terutama yang berkaitan dengan mekanisme ataupun komposisi keanggotaan badan legislatif nantinya jika sudah terbentuk. Mereka memperjuangkan sampai ketingkat pusat di Jakarta. 
Adanya Keppres Nomor 110 tahun 2000 tentang tatacara pembentukan DPRD Kota Batam telah menimbulkan perbedaan antara partai besar dengan partai "gurem". Perbedaan tersebut terletak pada jumlah kursi dewan juga karena tidak adanya politicall will dari partai besar untuk berkompromi dengan partai gurem. Adanya masalah tersebut maka dibentuk Dewan Pemantau Otonomi Daerah (DPOD) yang berfungsi sebagai dewan pemantau yang sifatya mengawasi dan mengontrol baik pelaksanaan pemerintah maupun kebijakan-kebijakan menuju pembentukan DPRD Kota Batam (Sutrisno, 2003: 21).

Dewan Pemantau Otonomi Daerah (DPOD) Kota Batam memiliki visi dan misi sbb:

1. Memantau mekanisme pembentukan DPRD Kota Batam sesuai undangundang dan peraturan yang berlaku.

2. Memantau pemilihan Walikota dan Wakil Walikota Batam.

3. Memantau pelaksanaan otonomi daerah dan pelaksanaan pembangunan di Kota Batam.

4. Menjadi wahana penampung dan penyalur aspirasi masyarakat Kota Batam, yang terabaikan.

Dalam melaksanakan tugas pengisian DPRD Batam yang berpedoman pada Kepmendagri Nomor 35 Tahun 1999 berisikan tentang pentingnya menyebut bahwa jumlah anggota DPRD Batam ditetapkan berdasarkan hasil pemilu 1999. Seluruh partai politik diwajibkan untuk mengusulkan kadernya yang akan menjadi calon legislatif, nama-nama kader dari setiap partai politik akan dimasukkan dalam Daftar Calon Sementara Baru (DCSB). Sehingga keanggotaan DPRD terbentuk berdasarkan SK Gubernur Riau Nomor KPTS $551 / \mathrm{X} / 2000$.

\section{b. Kedudukan dan Fungsi Lembaga DPRD Pada Sistem Pemerintahan Kota Batam}

Dewan Perwakilan Rakyat Daerah (DPRD) terdiri atas anggota partai politik (parpol) dari hasil pemilihan umum (pemilu) serta anggota TNI/Polri yang diangkat, mereka dipilih oleh rakyat sebagai penyambung aspirasi suara rakyat. Kinerja mereka ditunjukan untuk kesejahteraan rakyat Batam yang lebih baik. DPRD Kota Batam sebagai lembaga perwakilan rakyat daerah memiliki fungsi legislasi, anggaran dan pengawasan dalam melaksanakan demokrasi.

a. Memilih walikota dan wakil walikota

b. Mengusulkan pengangkatan dan dan pemberhentian walikota dan wakil walikota.

c. Bersama dengan walikota membentuk peraturan daerah (Perda)

d. Melaksanakan pengawasan terhadap pelaksanaan perda dan peraturan perudang-undangan lainnya seperti :

1) Melaksankan keputusan walikota

2) Pelaksanaan anggaran pendapatan belanja daerah (APBD) 
3) Kebijakan pemerintah daerah dan badan-badan yang dibina dan atau dibentuk oleh pemerintah termasuk aset-aset pemerintah daerah

e. Memberi pendapat dan pertimbangan kepada pemerintah daerah terhadap rencana perjanjian Internasional yang menyangkut kepentingan daerah, termasuk perjanjian antar daerah baik diminta maupuntidak diminta.

f. Memberi persetujuan pimpinan pemerintah daerah dari sumber dalam negeri untuk membiayai pemerintah.

g. Memberi persetujuan terhadap perjanjian kerjasama instansi yang dilakukan pemerintah Kota Batam bersama investor baik dari dalam maupun dari luar negeri.

h. Menampung dan menindaklanjuti aspirasi masyarakat dan daerah

i. Memilih wakil-wakil daerah sebagai anggota dewan pertimbangan otonomi daerah dari deaerah ke kota Batam.

Legislatif bekerja sama dengan eksekutif dalam menjalankan peran masing-masing sesuai dengan undang-undang. Kebijakan yang dibuat legislatif dan eksekutif adalah untuk kesejahteraan masyarakat dan masing-masing lembaga mempunyai kekuasaan untuk melakukannya. Hal ini relevan dengan pernyataan Miriam Budiardjo (2009: 20) bahwa pada prinsipnya pihak atau lembaga yang membuat kebijakan mempunyai kekuasaan untuk menjalankannya.

\section{Temuan Khusus dan Pembahasan}

\section{a. Partai Politik dan Keanggotaan DPRD Kota Batam}

Pemilihan Umum (Pemilu) Dewan Perwakilan Rakyat (DPR) dan Dewan Perwakilan Rakyat Daerah (DPRD) tahun 1999 diselenggarakan secara serentak pada tanggal 7 Juni 1999, untuk memilih anggota DPR serta DPRD (DPRD provinsi maupun DPRD kabupaten/kota) se-Indonesia. Masa reformasi telah membuka lebar kesempatan untuk mendirikan parpol, terbukti pada pemilu tahun 1999 jumlah partai politik (Parpol) ada 48 parpol yang lolos.

Provinsi Kepulauan Riau khususnya Kota Batam, parpol yang ikut serta dalam pemilihan sebanyak 33 parpol yaitu: Partai Indonesia Baru (PIB), Partai Kristen Nasional Indonesia, Partai Nasional Indonesia (PNI), Partai Ummat Islam (PUI), Partai Masyumi Baru (PMB), Partai Persatuan Pembangunan (PPP), Partai Demokrasi Indonesia Perjuangan (PDI.P), Partai Abul Yatama, Partai Kebangkitan Merdeka (PKMD), Partai Demokrasi indoesia (PDI), Partai Amanat Nasional (PAN), Partai Katholik Demokrat (PKD), Partai Pilihan Rakyat (PILAR), Partai Rakyat Indonesia (PARI), Partai Musyawarah Rakyat Banyak (PMB), Partai Bulan Bintang (PBB), Partai Keadilan (PK), Partai Nahdlatul Ummat (PNU), Partai Nahdlatul Islam Front Marhaenis (PNI-FM), Partai Ikatan Pendukung Kemerdekaan Indonesia (PARTAI IPKI), Partai Republik, Partai 
Golongan Karya (GOLKAR), Partai Persatuan (PP), Partai Kebangkitan Bangsa (PKB), Partai Uni Demokrasi Indonesia (PUDI), Partai Buruh Nasional (PBN), Partai Musyawarah Kekeluargaan Gotong Royong (P.MKGR), Partai Daulat Rakyat (PDR), Partai Cinta Damai (PCD), Partai Keadilan dan Persatuan (PKP), Partai Bhinneka Tunggal Ika Indonesia (PBI), Partai Nasional Demokrat (PND) dan Partai Pekerja Indonesia (PPI).

Parpol yang berhasil duduk menjadi anggota DPRD Kota Batam telah ditetapkan berdasarkan hasil pemilu 1999, parpol yang berhasil lolos duduk menjadi legislatif terdiri dari partai sebagai berikut :

a) PDI Perjuangan sebanyak 10 anggota

b) Partai Golkar sebanyak 6 anggota

c) PAN sebanyak 4 anggota

d) PKB sebanyak 2 anggota

e) PPP sebanyak 1 anggota

f) PBB sebanyak 1 anggota

g) Partai Keadilan sebanyak 1 anggota

h) PBI sebanyak 1 anggota

i) Dari TNI/Polri sebanyak 3 anggota.

Keanggotaan legislatif dari pusat sampai daerah tidak terlepas dari partai politik (parpol). Dalam suatu lembaga politik, partai bukan sesuatu yang dengan sendirinya ada. Kelahirannya mempunyai sejarah yang cukup panjang, sehingga dikatakan juga parpol adalah wadah atau kendaraan untuk duduk dilegislatif atau anggota legislatif berasal dari parpol. Seperti yang dijelaskan Rohaniah (2015: 249) bahwa anggota legislatif berasal dari parpol dan parpol merupakan organisasi negara.

\section{a) Keanggotaan DPRD Kota Batam dari Warga Tionghoa Periode 1999- 2004}

Hasil pemilu yang berlangsung pada 7 Juni 1999, di Kota Batam telah mewakilkan orang-orang pilihan yang diangkat oleh Parpol untuk duduk menjadi anggota DPRD Kota Batam. Ada 26 orang yang dilantik dan diambil sumpah untuk menjadi anggota DPRD Kota Batam periode 1999-2004 digedung Beringin Sekupangsebagai berikut:

Tabel. 1

Nama Anggota DPRD Terpilih Kota Batam Tahun 1999-2004

\begin{tabular}{|l|l|l|}
\hline NO & Nama Anggota DPRD Terpilih & Nama Partai \\
\hline 1. & Eddy Santoso & PDI-Perjuangan \\
\hline 2. & Rismar Munandar & PDI-Perjuangan \\
\hline 3. & Ibnu Hajar & PDI-Perjuangan \\
\hline 4. & Fransiscus Simbolon & PDI-Perjuangan \\
\hline
\end{tabular}




\begin{tabular}{|l|l|l|}
\hline 5. & LD Siburian & PDI-Perjuangan \\
\hline 6. & Soerya Respationo, SH & PDI-Perjuangan \\
\hline 7. & Sahat Sianturi & PDI-Perjuangan \\
\hline 8. & Dumoli Sirait, MBA & PDI-Perjuangan \\
\hline 9. & Abdul Karim & PDI-Perjuangan \\
\hline 10. & Ir. Saharman HD Manullang & PDI-Perjuangan \\
\hline 11. & Taba Iskandar, SH, MBA & Partai Golkar \\
\hline 12. & Drs. H Martioes Tanjung & Partai Golkar \\
\hline 13. & R. Edi Robert Siahaan & Partai Golkar \\
\hline 14. & Asmin Patros, SH & Partai Golkar \\
\hline 15. & Nuraini Marthen Langi & Partai Golkar \\
\hline 16. & Ir. M Nur Syafriadi & Partai Golkar \\
\hline 17. & Ir. M Nabil & Partai Amanat Nasional \\
\hline 18. & M Yasin & Partai Amanat Nasional \\
\hline 19. & Asman Abnur, SE, MBA & Partai Amanat Nasional \\
\hline 20. & Chablullah Wibisono & Partai Amanat Nasional \\
\hline 21. & H Saidun Khudri & Partai Kebangkitan Bangsa \\
\hline 22. & H Didi Suryadi & Partai Kebangkitan Bangsa \\
\hline 23. & Ahars Sulaiman, SH & Partai Persatuan Pembangunan \\
\hline 24. & Saptono Mustakim & Partai Bhinneka Tunggal Ika \\
\hline 25. & H Andi Ibrahim, MBA & Partai Bulan Bintang \\
\hline 26. & Amri Beddu, SE & Partai Keadilan \\
\hline
\end{tabular}

Sumber: Dokumentasi KPU Tahun 1999.

Pada pemilu tanggal 7 Juni 1999, warga Tionghoa yang lolos menjadi anggola legislatif adalah Saptono Mustakim perwakilan dari Partai Bhinneka Tunggal Ika (PBI) dan Asmin Patros perwakilan dari partai Golongan Karya (Golkar). Sosok Saptono Mustakim dan Asmin Patros, keduanya adalah tokoh yang cukup dipandang di daerah Dabo Singkep. Keikutsertaan Saptono Mustakim dengan Asmin Patros dalam pemilu tahun 1999, mendapat tanggapan yang positif dari masyarakat Batam pada umumnya.

\section{b) Keanggotaan DPRD Kota Batam dari Warga Tionghoa Periode 2004- 2009}

Pemilu periode kedua masa reformasi, di Indonesia serentak berlangsung pada 5 april 2004 diikuti oleh 24 partai politik. Hasil pemilu wilayah Batam pada untuk periode tahun 2004-2009 sebanyak 45 anggota, dari 45 anggota DPRD Kota Batam periode kedua ini dilantik pada tanggal 24 Agustus 2004 di gedung DPRD Kota Batam, melalui Surat Keputusan Gubernur Kepulauan Riau Nomor: ktsp 20/VIII/2004. Mereka yang dilantik adalah :

\section{Tabel. 2}

Nama Anggota DPRD Terpilih Periode Tahun 2004-2009 


\begin{tabular}{|c|c|c|}
\hline No. & Nama Anggota DPRD Terpilih & Nama Partai \\
\hline 1. & Jasarmen Purba & $\begin{array}{l}\text { Partai Nasional Indonesia } \\
\text { Marhaenisme (PNIM) }\end{array}$ \\
\hline 2. & Karles sinaga & $\begin{array}{l}\text { Partai Buruh Sosial Demokrat } \\
\text { (PBSD) }\end{array}$ \\
\hline 3. & Tan Syamsuddin & Partai Bulan Bintang (PBB) \\
\hline 4. & Hj. Suhaeni, SE & Partai Persatuan Pembangunan \\
\hline 5. & Abdul Rahman & Partai Persatuan Pembangunan \\
\hline 6. & H. Irwansyah & Partai Persatuan Pembangunan \\
\hline 7. & H. Sukri Fahrial & Partai Persatuan Pembangunan \\
\hline 8. & Yohannes, SH & $\begin{array}{l}\text { Partai Perhimpunan Indonesia Baru } \\
\text { (PPIB) }\end{array}$ \\
\hline 9. & Zakaria & Partai Demokrat \\
\hline 10. & Danir Tan & Partai Demokrat \\
\hline 11. & H. Irlan Gusti H. MK & Partai Demokrat \\
\hline 12. & Ir. Bastoni Solichin & Partai Demokrat \\
\hline 13. & H. Mawardi Harni, SE, MM & Partai Amanat Nasional (PAN) \\
\hline 14. & Dr. Ir. H. Chablullah Wibisono & Partai Amanat Nasional (PAN) \\
\hline 15. & Edward Brando & Partai Amanat Nasional (PAN) \\
\hline 16. & Yudi Kurnain & Partai Amanat Nasional (PAN) \\
\hline 17. & H. Askan Asrul Sany & Partai Amanat Nasional (PAN) \\
\hline 18. & Hj. Setyasih Priherlina & Partai Amanat Nasional (PAN) \\
\hline 19. & H. Didi suryadi & Partai Kebangkitan Bangsa (PKB) \\
\hline 20. & Hj. Hartini & Partai Kebangkitan Bangsa (PKB) \\
\hline 21. & H. Thamrin, SE & Partai Kebangkitan Bangsa (PKB) \\
\hline 22. & H. Jamhuri Muchtar & Partai Kebangkitan Bangsa (PKB) \\
\hline 23. & H. Amiruddin Dahad, MA & Partai Keadilan Sejahtera (PKS) \\
\hline 24. & H. Aris Hardy Halim, A.Md & Partai Keadilan Sejahtera (PKS) \\
\hline 25. & Muhammad & Partai Keadilan Sejahtera (PKS) \\
\hline 26. & Drs. Said Hasyim Alatas & Partai Keadilan Sejahtera (PKS ) \\
\hline 27. & Muhammad Zilzal & Partai Keadilan Sejahtera (PKS) \\
\hline 28. & Drs. H. Mustakim Husain & Partai Keadilan Sejahtera (PKS) \\
\hline 29. & Sahat Sianturi & PDI-Perjuangan \\
\hline 30. & Ir. Wardi Atmowiyono & PDI-Perjuangan \\
\hline 31. & HM. Soeryo Respationo, SH, MH & PDI-Perjuangan \\
\hline 32. & Husbandri & PDI-Perjuangan \\
\hline 33. & HM. Kholiq W, SH, MH & PDI-Perjuangan \\
\hline 34. & Abdul Karim & PDI-Perjuangan \\
\hline 35. & Ruslan & PDI-Perjuangan \\
\hline 36. & Drs. Christianto H. Rikumahu, ST & Partai Damai Sejahtera (PDS ) \\
\hline 37. & Pdt. Rudi Sembiring Meliala, ST & Partai Damai Sejahtera (PDS) \\
\hline 38. & Ir. Dameria Nadapdap & Partai Damai Sejahtera (PDS) \\
\hline 39. & Ir. Reinhard Hutabarat & Partai Damai Sejahtera (PDS) \\
\hline 40. & Drs. H. Gani Hasyim & Partai Golkar \\
\hline
\end{tabular}




\begin{tabular}{|l|l|l|}
\hline 41. & Amsin Patros, SH & Partai Golkar \\
\hline 42. & Raja Abdul Gani & Partai Golkar \\
\hline 43. & RE. Robert Siahaan & Partai Golkar \\
\hline 44. & Drs. Supandi Arim & Partai Golkar \\
\hline 45. & Ir. Onward C. Siahaan & Partai Pelopor \\
\hline
\end{tabular}

Sumber : Dokumentasi KPU Tahun 2004

Pemilu tahun 2004 telah membuktikan bahwa keikutsertaan warga Tionghoa dalam politik di Batam semakin bertambah, warga Tionghoa yang lolos menjadi anggota legislatif periode 2004-2009 sebanyak 4 orang adalah :

1. Yohannes perwakilan dari Partai PPIB

2. Danir Tan perwakilan dari Partai Demokrat

3. Ir. Bastoni Solichin perwakilan dari Partai Demokrat

4. Asmin Patros perwakilan dari Partai Golkar

\section{Peran Politik Warga Tionghoa yang menjadi Anggota Legislatif pada Periode 1999-2009}

\section{a) Peran Legislasi}

Peran legislasi dari anggota DPRD Kota Batam mempunyai tugas dalam menyusun dan menyiapkan perundang-undangan dalam bentuk rancangan peraturan daerah bersama-sama dengan pemerintah daerah sebelum diadakannya rapat paripurna dan menyampaikan hasil laporan secara tertulis dan dibacakan dalam rapat paripurna. Hal ini masih relevan dengan pendapat dari Miriam Budiardjo (2009: 323), mengatakan fungsi utama dari peran legislasi terletak di bidang perundang-undangan. Pendapat tersebut memiliki kesamaan dengan kinerja DPRD Kota Batam, dalam menyusun dan menyiapkan perundangundangan dalam bentuk peraturan daerah (perda) Kota Batam.

Fungsi Legislasi dari anggota DPRD Kota Batam dapat meliputi :

1) Menyusun dan menyiapkan rancangan peraturan daerah bersama-sama pemerintah daerah diminta atau tidak diminta sebelum disampaikan oleh pemerintah daerah kepada DPRD dalam rapat paripurna.

2) Menyusun dan menyiapkan rancangan peraturan daerah yang berasal dari prakarsa DPRD.

3) Dalam hal panitia legislasi telah selesai melaksanakan tugasnya maka diwajibkan menyampaikan laporan secara tertulis dan dibacakan dalam rapat paripurna.

Peraturan daerah (Perda) yang disusun dan dibicarakan dalam persidangan setiap tahun membahas masalah yang berbeda-beda. Permasalahan yang cukup menantang berkaitan dengan jumlah penduduk Batam. 
Peran legislasi dari anggota DPRD Kota Batam dalam mengatur dan membahas tentang peraturan daerah (Perda) bersama kepala daerah Kota Batam yang dilakukan oleh anggota DPRD dari tahun 2000 sebanyak 18 Perda, tahun 2001 sebanyak 20 Perda, tahun 2002 ada 6 Perda, tahun 2003 sebanyak 8 Perda, tahun 2004 sebanyak 5 Perda, tahun 2005 sebanyak 5 Perda, tahun 2006 sebanyak 9 Perda, tahun 2007 sebanyak 17 Perda, tahun 2008 sebanyak 4 Perda dan tahun 2009 sebanyak 14 Perda .

Kinerja DPRD Kota Batam dimulai pada tahun 2000 dengan mengesahkan 18 Perda, tahun 2000 merupakan langkah awal bagi anggota legislatif mulai bekerja sebagai wakil rakyat. Diawali dengan mengeluarkan SK Nomor: 01/KPTS/DPRD/XI/2000, yang mengatur tentang pembentukan panitia kerja, pembuatan tata tertib DPRD Kota Batam, disahkan pada tanggal 6 November 2000. Pembahasan selanjutnya membahas tentang pembentukan komisi DPRD Kota Batam yang terbentuk menjadi 5 komisi, yaitu komisi A menangani bidang hukum, komisi B menangani bidang perekonomian, komisi $\mathrm{C}$ menangani bidang keuangan dan anggaran, komisi D menangani bidang pembangunan prasarana dan lingkungan hidup sedangkan komisi E menangani bidang kesejahteraan rakyat. Anggota legislatif mulai melakukan peran legislasi sebagai wakil rakyat, terutama untuk kesejahteraan masyarakat Batam.

Pada tahun 2001 DPRD Kota Batam menyetujui 20 Perda, kinerja DPRD yang cukup mengundang kontroversi dapat dilihat dari peran legislasi membahas tentang pemilihan Walikota dan Wakil Walikota Batam secara langsung, yang tertuang dalam SK Nomor 19/KPTS/DPRD/I/2001 tentang panitia teknis pelaksanaan pemungutan suara pemilihan Walikota dan Wakil Walikota Batam periode 2001-2006, calon terpilih yakni Drs. Nyat Kadir sebagai Walikota dan Asman Abnur, SE, MBA sebagai Wakil Walikota Batam. Pembahasan lain DPRD membahas tentang judi dan prostitusi yang cukup berkembang di Batam.

Di tahun 2002 DPRD Kota Batam menyetujui sebanyak 6 Perda, DPRD Kota Batam lebih berperan dalam hal peningkatan iklim investasi, DPRD Kota Batam mengeluarkan SK No.4/KPTS/DPRD/I/2002 tentang pembentukan Badan Usaha Milik Daerah (BUMD), selain itu juga menangani Pajak Pertambahan Nilai (PPN) dan pembahasan RUU tentang Free Trade Zone (FTZ). Dilanjutkan pada tahun 2003 dengan menyetujui sebanyak 8 Perda, dapat dilihat peran legislasi DPRD Kota Batam dengan mengeluarkan SK Nomor 3/KPTS/DPRD/IV/2003 tentang kepariwisataan di Kota Batam. Hal ini lebih cenderung kebidang sosial kemasyarakatan, menyangkut masalah perdagangan wanita dan anak (trafficking) dan membahas tentang Upah Minimum Kota (UMK) Batam.

Pada tahun 2004 peran legislasi dari anggota DPRD Batam dengan mengesahkan sebanyak 5 Perda, peran legislasi DPRD Batam dapat dilihat dari segi tata ruang Kota Batam. Hal ini dapat dilihat dari penertiban terhadap tempat- 
tempat hiburan yang bertentangan dengan norma agama, budaya dan hukum positif.

Penjelasan diatas adalah beberapa bagian dari peran legislasi anggota DPRD Kota Batam, kinerja para anggota legislatif sebagai wakil rakyat periode 2000-2004. Peran politik warga Tionghoa yang menjadi anggota legislatif periode pemilu 1999-2004, dari perwakilan warga Tionghoa yaitu Saptono Mustakim yang menjadi wakil ketua komisi A yang menangani bidang hukum dan pemeritahan, Asmin Patros menjadi ketua komisi C yang manangani bidang keuangan dan anggaran.

Kinerja anggota DPRD Kota Batam untuk periode kedua sudah cukup membaik, kinerja mereka melanjutkan dari keanggotaan periode pertama DPRD Kota Batam. Pada tahun 2005 peran legislasi dengan mengesahkan sebanyak 5 Perda oleh anggota DPRD Kota Batam, hal yang cukup menarik seperti membahas tentang pemekaran dan perubahan dan pembentukan Kecamatan dan Kelurahan dalam daerah Kota Batam yang tertuang dalam perda Kota Batam No.2 yang dikeluarkan pada tahun 2005. Pada tahun 2006 disahkan sebanyak 9 Perda oleh DPRD Kota Batam, seperti Perda Kota Batam No.1 membahas tentang pembentuakan susunan organisasi dan tata kerja rumah sakit umum daerah Kota Batam, hal ini berkaitan dengan mulai banyaknya dibangun fasilitas pelayanan dibidang kesehatan di Batam, melihat kondisi rumah sakit di Batam saat itu masih sedikit.

Tahun 2007 kinerja anggota legislatif dilihat dari fungsi legislasi yang cukup menonjol di tahun 2007 dengan mengesahkan sebanyak 17 Perda, Perda yang cukup menarik adalah Perda No.2 yang menangani masalah tentang susunan organisasi dan tata kerja wakil rakyat, dari tingkat tinggi seperti DPRD Kota Batam dan tingkat redah yaitu kecamatan dan kelurahan di Kota Batam, serta adanaya pembentukan satuan polisi pamong praja Kota Batam, hal ini berkaitan dengan ketertiban umum.

Kinerja DPRD pada tahun 2008 secara legislasi mengesahkan 4 Perda, selain membahas APBD setiap tahunnya, hal yang cukup menarik tentang perubahan kedua atas Perda Kota Batam No. 15 tahun 2001 tentang pajak-pajak daerah Kota Batam. Pada tahun 2009 anggota DPRD Batam, dilihat dari peran legislasi yaitu dengan mengesahkan sebanyak 14 Perda, diakhir jabatan anggota DPRD Batam periode kedua, banyak masalah yang perlu diselesaikan, seperti yang cukup menarik perhatian adalah Perda No.5 tentang retribusi penggunaan tanah dan atau bangunan yang dikuasai oleh pemerintah daerah untuk pemasangan reklame dan Perda No.8 tentang penyelenggaraan administrasi kependudukan Kota Batam. kedua hal ini saling berkaitan karena musim kampanye untuk pemilu periode 2009-2014. 
Periode kedua DPRD Kota Batam tahun 2004-2009, keanggotaan dari warga Tionghoa yang menjadi anggota DPRD Batam sebanyak 4 orang yaitu Asmin patros, Yohannes, Bastoni Solichin dan Danir Tan. Peran politik dari perwakilan warga Tionghoa yang menjadi anggota legislatif, periode 2004-2009 yaitu Bapak Asmin Patros menjadi anggota komisi II menangani bidang perekonomian dan keuangan, Bapak Danir Tan menjadi anggota komisi III menangani masalah bidang pembangunan, Bapak Bastoni Solichin masuk menjadi anggota komisi I menangani masalah bidang pemerintahan dan Bapak Yohannes menjadi anggota komisi II menangani bidang perekonomian dan keuangan.

Pada periode ini, peran legislasi anggota DPRD dari warga Tionghoa sama dengan periode sebelumnya yaitu menyusun, menyiapkan rancangan peraturan daerah Kota Batam. Dari banyak Perda yang telah dibuat, secara umum peran legislasi dari anggota DPRD Kota Batam masih relevan dengan pendapat ahli seperti pendapat Kusnardi (2008: 265) mengatakan bahwa fungsi legislasi yaitu DPRD bersama Gubernur untuk tingkat I dan bersama Bupati atau Walikota Madya untuk Dati II yaitu menyusun dan menetapkan peraturan daerah (Perda). Hal tersebut juga relevan dengan pendapat Toto Pribadi (2010: 5.29) menjelaskan bahwa fungsi legislasi adalah fungsi untuk membentuk undang-undang.

\section{b) Peran Kontrol}

Peran kontrol dari anggota DPRD Kota Batam dapat diwujudkan dalam bentuk pengawasan terhadap pelaksanaan undang-undang, peraturan daerah, keputusan kepala daerah serta kebijakan yang ditetapkan oleh pemerintah daerah. Peran kontrol melalui pengawasan dilakukan dalam sidang paripurna dengan hakhak kontrol seperti hak bertanya, interpelasi, angket dan mosi. Rapat yang diselenggarakan oleh DPRD Kota Batam seperti: rapat paripurna, rapat paripurna istimewa, rapat paripurna khusus, rapat fraksi, rapat pimpinan dewan, rapat panitia musyawarah, rapat komisi, rapat gabungan komisi, rapat panitia anggaran, rapat panitia khusus, rapat kerja dan rapar dengar pendapat (hearing).

Peran kontrol dari anggota legislatif sebagai badan pengawasan pelaksanaan peraturan daerah, sehingga diharapkan kelancaran dalam melakukan kebijakan-kebijakan yang telah ditetapkan dalam bentuk Perda yang telah disepakati dalam rapat paripurna. Berdasarkan hasil penelitian tentang fungsi kontrol anggota legislatif di Kota Batam, masih relevan dengan pendapat Miriam Budiardjo (2009: 324) badan legislatif memiliki fungsi kontrol dalam mengawasi aktivitas kinerja badan eksekutif supaya sesuai dengan kebijakan yang diterapkan, hak-hak kontrol tersebut meliputi hak bertanya, interpelasi, angket dan mosi.

Peran kontrol anggota DPRD Kota Batam untuk periode 1999-2009, DPRD melakukan berbagai upaya untuk mengontrol jalannya roda pemerintahan sesuai koridor yang telah ditetapkan. Peran kontrol melalui hak bertanya berkaitan 
dengan setiap undang-undang atau Perda yang telah disetujui, jika anggota DPRD menggunakan hak bertanya secara tertulis maka pemerintah daerah menjawab dengan tertulis, jika DPRD menggunakan hak bertanya secara lisan, maka pemeritah daerah dapat menjawab dalam bentuk lisan secara lebih jelas tentang hal yang terkandung dalam pertanyaan tersebut, DPRD menggunakan hak bertanya pada saat rapat paripurna berlangsung.

Peran kontrol meliputi hak interpelasi yaitu berkaitan dengan hak anggota DPRD Kota Batam untuk meminta keterangan terhadap setiap kebijakan yang telah dikeluarkan oleh pemerintah daerah yang penting dan strategis serta berdampak luas pada kehidupan masyarakat, daerah dan negara. Anggota DPRD dapat mengajukan usul kepada ketua DPRD, untuk meminta keterangan kepada pemerintah daerah secara lisan atau tertulis, terhadap suatu kebijakan yang dikeluarkan oleh pemerintah daerah saat rapat paripurna berlangsung.

Peran kontrol meliputi hak angket artinya anggota DPRD Kota Batam memiliki hak untuk melakukan penyelidikan terhadap kebijakan pemerintah daerah yang penting dan strategis serta berdampak luas pada kehidupan masyarakat, daerah dan negara yang diduga bertentangan dengan peraturan perundang-undangan. Hak angket dapat dilakukan oleh anggota DPRD dengan memberikan usul untuk melakukan penyelidikan yang dilakukan oleh panitia khusus (pansus) dan hasil penyelidikan akan dilaporkan dalam rapat paripurna.

Hak mosi yang dimiliki oleh keanggotaan DPRD, maksudnya adalah dengan memiliki hak untuk mencarikan pengganti kepada keanggotaan yang kosong di pemerintahan setempat, DPRD berhak membahas untuk mencarikan calon pengganti. Penjelasan tersebut sesuai dengan pendapat Miriam Budiardjo (2009: 326) membahas tentang hak mosi merupakan hak kontrol yang paling ampuh.

Berdasarkan uraian diatas, menjelaskan fungsi DPRD sebagai fungsi kontrol untuk mengawasi jalannya Perda yang telah ditetapkan bersama dengan kepala daerah saat sidang paripurna. Anggota DPRD berhak penuh dalam pengawasan dalam proses berjalannya Perda tersebut, agar sesuai dengan kepentingan masyarakat pada umumnya.

\section{c) Fungsi lainnya}

Fungsi lainnya dapat dilihat dari peran anggaran yang diwujudkan dalam meyusun dan menetapkan Anggaran Pendapatan dan Belanja Daerah (APBD) bersama pemerintah daerah. Fungsi anggota legislatif dari peran anggaran dalam menyusun anggaran belanja DPRD dan memberikan saran terhadap penyusunan anggaran belanja sekretariat daerah, memberikan saran dan pendapat berupa pokok-pokok pikiran DPRD kepada kepala daerah, serta mempersiapkan 
rancangan anggaran dan belanja daerah selambat-lambatnya lima bulan sebelum ditetapkannya APBD yang disampaikan dalam sidang paripurna.

Pendapat Yoyoh Rohaniah dan Efriza (2015: 292) mengatakan kedaulatan ada ditangan rakyat, maka badan legislatif menjadi badan yang memiliki hak menyelenggarakan kedaulatn tersebut, sehingga badan eksekutif merupakan penyelenggara kebijakan umum.

Peran anggota DPRD dalam bidang anggaran cukup penting, hal ini dibentuk panitia anggaran yang beranggotakan dari perwakilan komisi dan fraksi. Tugas dari panitia anggaran yaitu memberikan saran dan pendapat berupa pokokpokok pikiran DPRD kepada kepala daerah, dalam mempersiapkan rancangan APBD selambat-lambatnya lima bulan sebelum ditetapkannya APBD tersebut. DPRD juga memiliki tugas menyusun anggaran belanja DPRD dan memberikan saran dalam penyusunan anggaran belanja sekretariat DPRD.

Hasil penelitian yang telah dilakukan oleh penulis tentang peran warga Tionghoa yang menjadi anggota legisatif Kota Batam tahun 1999-2009, dapat dilihat dari peran legislasi yang membuat peraturan daerah. Peran kontrol atau pengawasan yang meliputi hak bertanya, hak interpelasi, hak angket dan hak mosi. Peran lainnya dapat dilihat dari anggaran yang berkaitan dengan APBD Kota Batam. Anggota DPRD Kota Batam dari warga Tionghoa, mereka bekerja sesuai aturan yang ada, dalam hal ini mereka bersifat umum, tidak memihak manapun walaupun mereka dari warga keturunan Tionghoa.

Dari beberapa hasil wawancara, dokumen yang penulis dapatkan, dapat diasumsikan bahwa fungsi anggaran yang dilaksanakan oleh anggota DPRD Kota Batam khususnya perwakilan warga Tionghoa sudah cukup baik. Sesuai dengan pendapat Toto Pribadi (2010: 5.25) yang menjelaskan bahwa fungsi DPRD dalam hal anggaran yaitu menetapkan APBD bersama dengan pemerintah daerah.

\section{F. Kesimpulan dan Saran}

\section{Kesimpulan}

Berdasarkan hasil penelitian dan pembahasan yang telah penulis lakukan, maka terdapat beberapa kesimpulan sebagai berikut :

1. Perwakilan warga Tionghoa yang duduk menjadi anggota DPRD Kota Batam, berdasarkan keputusan hasil pemilu 1999 adalah Saptono Mustakim dan Asmin Patros, mereka dua bersaudara yang lolos menjadi anggota legislatif Batam dari partai yang berbeda. Saptono Mustakim perwakilan dari PBI (Partai Bhinneka Tunggal Ika) dan Asmin Patros perwakilan dari Partai Golkar (Golongan Karya). Mereka dilantik menjadi anggota DPRD Kota Batam untuk periode 1999-2004. 
2. Pada tahun 2004, keikutsertaan warga Tionghoa dalam pemilu mengalami peningkatan, warga Tionghoa yang berhasil terpilih menjadi anggota DPRD Kota Batam ada 4 orang, pertama Yohannes perwakilan dari PPIB, kedua Danir Tan perwakilan dari partai Demokrat, ketiga Ir. Bastoni Solichin perwakilan dari partai Demokrat dan keempat Asmin Patros dari partai yang sama dengan pemilu sebelumnya yaitu Golkar.

3. Terjadinya peningkatan jumlah warga Tionghoa yang duduk sebagai anggota DPRD Kota Batam tidak terlepas dari peranan yang mereka mainkan saat menjadi anggota legislatif.

4. Peran anggota legislatif diantaranya dilihat dari :

a. Fungsi legislasi, dimana dari tahun 1999-2009 telah berhasil membuat Perda sebanyak 106 peraturan daerah yang telah ditetapkan.

b. Fungsi kontrol berkaitan dengan pengawasan, anggota DPRD berhak mengawasi jalannya kinerja para anggota eksekutif dalam menjalankan Perda yang telah ditetapkan bersama kepala daerah saat sidang paripurna.

c. Fungsi lainnya terkait dengan anggaran yang ditetapkan dalam bentuk APBD yang setiap tahun akan dibahas bersama badan eksekutif saat sidang paripura.

\section{A. Saran}

Saran yang dapat penulis berikan setelah melakukan penelitian dan pembahasan sebagai berikut :

1. Lembaga legislatif dapat lebih meningkatkan peranannya dalam mewadahi aspirasi masyarakat Kota Batam.

2. Kepada anggota DPRD Kota Batam dari warga Tionghoa diharapkan dapat meningkatkan kinerja sebagai wujud nyata atas kepercayaan yang sudah diberikan oleh warga Tionghoa.

3. Kepada Pemerintahan Kota Batam senantiasa saling bekerja sama dengan anggota DPRD, supaya terwujudnya kesejateraan warga Batam.

4. Diharapkan DPRD Kota Batam dapat meningkatkan mutu dan kualiatas pendidikan yang ada di wilayah Kota Batam terutama wilayah pelosok, dari level pendidikan terendah sampai tertinggi. 


\section{Daftar Pustaka}

Budiardjo, Miriam. 2009. Dasar-Dasar Ilmu Politik. Jakarta: Penerbit PT Gramedia Pustaka Utama.

Gottschalk, Louis. 1983. Metode sejarah. Yogyakarta, Ombak.

Hafsah, Mohammad, Jafar. 2001. Politik Untuk Kesejahteraan Rakyat. Jakarta: PT. Pustaka Sinar Harapan.

Hidajat, Imam. 2012. Teori-Teori Politik. Malang: SETARA Press.

Indrayana, Denny. 2011. Indonesia Optimis. Jakarta: PT. Bhuana Ilmu Populer.

Idrus, Muhammad. 2009. Metode Penelitian Ilmu Sosial. Jakarta: Erlangga.

Kuntowijoyo. 2003. Metodologi Sejarah. Yogyakarta: PT Tiara Wacana.

Kusnardi, \& Saragih, Bintan, R. 2008. Ilmu Negara: Gaya Media Pratama.

Lan, Noi, Joe. 2013. Peradaban Tionghoa Selayang Pandang. Jakarta: Pustaka LP3ES Indonesia.

Nurwijayanti, septe \& Prasetyoningsih, Nanik. 2009. Politik Ketatanegaraan. Yogyakarta: LabHukum Fakultas Universitas Muhammadiyah Yogyakarta.

Pribadi, Toto. 2010. Sistem Pemerintahan Indonesia. Jakarta: Universitas Terbuka.

Rohaniah, Yoyoh \& Efriza. 2015. Pengantar ilmu Politik. Malang: Intrans Publishing.

Sugiyono. 2012. Metode Penelitian Pendidikan. Bandung: Alfabeta.

Suryadinata, Leo. 2002. Negara dan Etnis Tionghoa Kasus Indonesia. Jakarta: Pustaka Populer Gramedia.

Sutrisno, Edi, dkk. 2006. Tionghoa Batam dulu dan Kini. Batam: Batam Link Publisher. 
Sutrisno, Edi, dkk. 2003. Sebuah Goresan Sejarah Dewan Perwakilan Rakyat Daerah Kota Batam: Batam Link Publisher. 